\title{
第 2 回流れの可視化講習会報告*
}

佐 賀 徹 雄**

\section{Report on the Second Short Course of Flow Visualization}

\section{Tetsuo SAGA}

第 2 回流れの可視化講習会は昭和62年 5 月 11 日 （月）, 12 日（火）の2 日間，東京の野口英世記念 会館で開催された。

第 1 回講習会を開催してからすでに 4 年が経過 し，この間に流れの可視化技術は著しく発展, 変 化し，その応用範囲も拡大した。これらの情況に 対応しつつ流れ可視化技術の普及と最新の技術の 把握を目的として第 2 回講習会が企画・実行され た。今回の講習会は，最近の可視化技術を集大成 した「新版 流れの可視化ハンドブック」(1986 年10月発行）の内容にもとづ，「流れの可視化 一基礎技術と最近の進歩」という内完で構成され た。本構習会では「新版 流れの可視化ハンドブ ック」を主テキストとして使用するとともに，補 助的に副テキストを併用した講義が行われた。こ の副テキストは各講師が最新の情報あるいはハン ドブックの説明が不足する部分について補足した もので，さらに機器展示各社が出展した機器の説 明を揭載して受講者への便宜を計った。講習会の 概要を表 1 に示す。プログラムは大別して(1)流れ の可視化手法とその応用方法といら基礎技術の明 紐な解説，(2)流れの可視化に最近導入されている 技術すなわち，物理量の測定技術，レーザー利用 技術およびュンピュータ利用技術等の解説といら 内容で作成された。

第 1 日目前半は主に可視化技術に関する講義が 行われた。まず，荒川講師から可視化技術として 一般的な油膜法, タフト法に括ける細かいテクニ ックや得られた結果の解釈について注意すべき点 などについての講義があった。つぎに，注入トレ 一サ法, 化学反応トレーサ法について岡本講師の 講義があり，液晶粒子トレーサによる流れパター ンと温度分布の同時可視化等についての興味深い 解説がなされた。つづいて，中山講師による電気

$*$ 原稿受付 昭和62年 8 月 6 日, ${ }^{* *}$ 東京大学生産技術研究所
制御法および高山講師による光学的可視化法の講 義が行われた。最後に，これらの可視化実験に抏 ける手法の選択と組み合わせの指針について，実 例を挙げた講義が明石講師により行われた。第1 日目後半はセンサとコンピュータシステムからな る物理量の測定方法と結果の表示方法についての 講義で, 吉田講師よりサーモグラフ法による温度 测定とコンピュータトモグラフィによる流れ場の 三次元解析方法についての解説が，藤田講師によ る音の発生や伝搬を計測する音響インテンシティ 法についての解説があった。第 2 日目前半はレー ザ利用の可視化技術についての講義が行われた。 まず，川橋講師よりレーザスペックル法による速 度測定とレーザ誘起螢光法による希薄気体の流れ の可視化法等についての講義があり，つづいて然 焼を伴う流れをレーザ干涉法を利用して温度と濃 度を同時に計測する方法について柏木講師の講義 があった。レーザ利用技術のとりまとめとして管 講師より，レーザの基本原理やレーザの仕様ある いはレーザ利用にあたっての問題点, 使用上の注 意事項を含めた講義があった。第 2 日目後半はコ ンピュータを利用した画像処理技術に関する講義 があった。まず，坂上講師より画像処理の専門家 の立場から画像処理の概念, 妈理の可能性, ソフ トウェアパッケージの利用方法等についての講義

表 1 プログラムの概要

\begin{tabular}{|c|c|c|c|c|c|}
\hline \multicolumn{3}{|c|}{$5 / 1119(\mathrm{~A})$} & \multicolumn{3}{|c|}{5 月12日（火） } \\
\hline $9: 30$ & $\begin{array}{l}\text { ・壁誼トレース泣 } \\
\text { タフト法 }\end{array}$ & 箈川思无 & $9: 00$ & 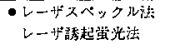 & 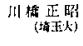 \\
\hline $10: 20$ & 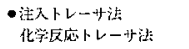 & 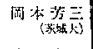 & $9: 50$ & 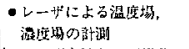 & 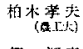 \\
\hline $11: 10$ & 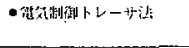 & 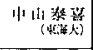 & $10: 40$ & 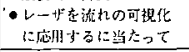 & 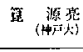 \\
\hline $12: 00$ & \multicolumn{2}{|c|}{ 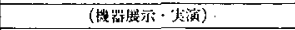 } & $11: 40$ & \multicolumn{2}{|c|}{ 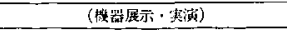 } \\
\hline $13: 30$ & 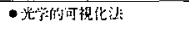 & 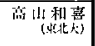 & $13: 00$ & 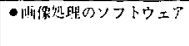 & 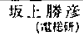 \\
\hline $14: 20$ & 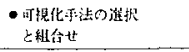 & 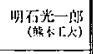 & $13: 50$ & 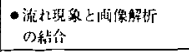 & 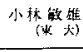 \\
\hline $15: 20$ & \multicolumn{2}{|l|}{ 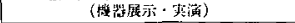 } & $14: 40$ & \multicolumn{2}{|c|}{ 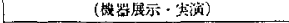 } \\
\hline $16: 00$ & $\begin{array}{l}\text { ・サーモグラフ法 } \\
\text { コンピーータトモグフフ }\end{array}$ & 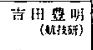 & $15: 20$ & 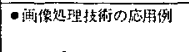 & 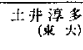 \\
\hline $\begin{array}{r}16: 40 \\
-17: 20\end{array}$ & 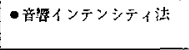 & 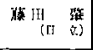 & $\begin{array}{l}16: 10 \\
-17: 00\end{array}$ & 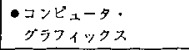 & 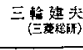 \\
\hline
\end{tabular}


がなされた。つづいて小林講師より流れの可視化 画像に適応されている画像処理とその処理方法に ついて事例を挙げての講義があり, 計測法として の精度評価の必要性が生じていることなどの説明 があった。つぎに，土井講師より，可視化画像の 三次元計測, 認識の方法とその経時変化を定量化 する万法についての講義があ到た。最後に, 三輪 講師より流れをコンピュータにより数值的にシミ ュレーションし，その解析結果を表現するための コンピュータグラフィクスの技術についてハード ウェア，ソフトゥェアの両面から説明があり，効 果的な映像表現方法について実例をむって講義が なされた。

以上, 受講者にとっては日数の割合にはやや内 容が多くなり，概括的になってしまった部分もあ るが，これは上記のように第 1 回目の講習会から 4 年経過し可視化技術全般についての進展と, そ の中での特に進歩の激しいレーザ関係の可視化， コンピュータ利用の可視化の全容を紹介したため である。したがって今後、テーマを絞った詳しい 内容の講習会, セミナーの開催が企画されるもの と思われるので関心のあるテーマを選んで受講を 予定していただきたい。

本講習会の受講者は 171 名に達し，その内訳は 本会会員112名, 学生12名, 共催・協賛学会員, 非会員47名であった。このうち企業からの受講者 は120名にの涼り，企業において可視化技術が多 用されていることが推察された。また, 受講者の 専門分野も機珹, 航空, 土木, 建築, 化学, 医 学, 農学および最近最も注目されているマイクロ エレクトロニクス分野へと多岐にわたって扣り， 可視化の応用分野が広がり各分野で流れに関する 多くの問題をかかえ，その解決策を模索している ことがうかがわれた。

講習会は野口記念会館の全館を使用して行われ た。講義は2 階ホールで，またホール前では可視 化写真（流れの可視化展, 流れの可視化写真集か ら選択）の展示を行った。休嚊時間には講義ホー ルで本会作成のビデオ「流れは生きている」を上 映するなど，本会の活動の一部も紹介した。

講習の内容の理解を深めるため, 可視化の機器 展示と実演を 1 階の四つの会議室を使用して行っ
た。機器展示業者 22 社と中山, 田古里, 谷田教授 および害行委員の協力を得て，講習内容に関連す る展示・寒演が行われた。主な内容は可視化材料 展示, 電気制御法 (火花追跡法, スモークワイヤ 法)，レーザライトシートの可視化システム，サ 一モグラフ法による温度計測, 液晶による温度計 测，シュリーレン法と画像計測，トレーサ法と画 像処理による速度計測, 数値計算結果の動画表示 および三次元表示システムなどである。このほか にも, 超高速ビデオカメラ, 流体計測装置, シュ リーレン，マッハッェンダ装置，スリット光源， 画像処理装置等が会場一杯に展示され，笑演が行 われた。受講者の参加による実習は会場の関係で 残念ながら行らことはでさなかった。さらに，機 器展示会場の一画には相談コーナーを設置し, 中 山, 田古里, 谷田教授に相談員を依頼し, 受講者 の相談を受けていただいた。この相談コーナ゙ーは 受講者に大变に好評で，可視化で著名な 3 人の先 生方に直接問題点を相談できたため熱心な質疑応 答が交わされた所定の時間内では終了しない注ど であった。

また，第 1 日目の夕刻からは同会館内で留親会 が開催された。参加者は45名で, 秋野委員（原子 力研究所）の司会のもとにアトラクションビデオ などを鑑賞しながら，特に参加を打願いした機器 展示各社の代表者の方々 々情報交換等が行われた

以上が第 2 回講習会の概要である。本講習会で の講義が生かされ，流れの可視化技術がより多く の研究者に広い分野で応用され，そのことにより さらに技術が発展することを願らものである。最 後に, 受講者へのアンケートのらち本講習会に対 する意見の主なものを二，三紹介し，今後の講習 会の参考とさせていただく。(1)講留会の定期的な 開催と回数の増加，(2)テーマを絞った具体的な内 容の講義。可視化の動機之問題解決への手順。， ウハウの公開，(3)実留を含む講義などであった。

なお，第 2 回講習会は下記の実行委員会の委員 によりその講想と内容が検討され，運営がなされ たことを付記する。

実行委員会 : 小林敏雄 (委員長), 秋野詔夫, 加 藤信介, 神崎 毅, 高木通俊, 武井幸雄, 田古里 哲夫, 土井淳多, 藤田 泶, 吉田豊明, 佐賀徹雄 